\title{
The Interaction of Development and Culture
}

\author{
Ivan Manyonga \\ Institute of Development Studies, University of Vienna, Vienna, Austria \\ *Corresponding Author: ivanjune3@gmail.com
}

Copyright $\mathrm{C} 2017$ by authors, all rights reserved. Authors agree that this article remains permanently open access under the terms of the Creative Commons Attribution License 4.0 International License

\begin{abstract}
The interaction of development and culture is an interesting discourse in the field of international development. In this field many studies on culture employs qualitative methodologies to obtain answers but, this paper uses quantitative approach to ignite a deep qualitative explanation on the fusion of culture and development. To establish the impact of development on culture change, access to electricity is treated as the main indicator of community development. Two provinces in Zimbabwe with contrasting levels of development were purposefully sampled in order to test the formulated working hypothesis that, "development has an effect on main attributes of an indigenous culture". This was followed by administration of an identical survey instrument carrying main attributes of indigenous Zimbabwean culture in the sampled two provinces. Multiple regression analysis techniques using Ordinal Least Squares were performed on the collected provincial data. Results failed to reject the research working hypothesis on the following attributes of culture; Language use among youth, indecent assault criminal cases, traditional and contemporary music while the working hypothesis was rejected on love relationships, dressing, and foreign music, language use with elders, robbery and drug use criminal cases.
\end{abstract}

Keywords Culture Attributes, Development, Harare Province, Manicaland Province, Regression Models

\section{Introduction}

Transition to a fully developed or industrialised state is a major battle which third world countries are fighting as they quest for their economies to emulate industrialized countries. The path to industrialization in third world states is not overnight event but, an enormous task characterized by radical fight to many obstacles such as deep rooted corruption, changing people's mind sets and shaping development initiatives to fit a given cultural context. Since development occurs in a community, the people's culture has to be considered because development initiatives and peoples culture interact in a complex way. In rolling out the process of development, a critical question linked to the chicken and egg debate needs to be carefully considered. What comes first between development and culture and what affects the other? Is it development which affects culture or it is culture which shapes development"? These two concepts are connected and the point of departure to clarify these seemingly simple but, mind boggling questions is the inherent need to spell out clear definitions of the concept of culture and development.

\subsection{Defining Culture and Development}

\subsubsection{What is culture?}

Shoremi, [1] defined Culture as the completeness of people's social conduct seen from their material and non-material aspects of life such as belief systems, clothing, norms and values. Ifenyinwa \& Mbakogu, [2] postulate that culture is comprised of material and non-material expressions of any society. This includes social, scientific, artistic and technological expressions shared by people of the same ethnicity, nationality or supra-nationality living within the same geographical boundaries. Culture depicts similarities among societies within the same territories and fosters a feeling of togetherness which is passed to future generations. Furthermore, certain features of culture shared by members of a community are not genetically transmitted but historically transmitted throughout generations. Culture is dynamic and is created by a process of adjustment to social setting [3 p 3]. Accordingly culture is thus, network of traits learned by interaction or deduced from history. In a nutshell, whichever definition of culture is proposed; it is regulated by unconscious shaping of people's attitudes, personalities and belief systems. Man is therefore useless without culture because the pride of any society lies in its culture. There is no society worldwide which is great without reference to its culture, [4 p 103].

\subsubsection{The concept of development}

Depending on the emphasized characteristics, different authors define 'development' differently. There is no one size fits all definition. Thomas, asserts that "development is contested, complex, and ambiguous concept", [5 p 1]. 
However, the different multiple scholarly definitions seem to agree that "the process of development" refers to change in different aspects of human life and that one of the simplest definitions of "development" is the notion of good change, [6]. In his attempt of providing a satisfactory definition of "development" Thomas, [5] notes that three different but related views have to be regarded: first, 'Development' as a long term process of structural societal transformation; second, 'Development' as a short-to-medium term outcome of desirable targets; and third, 'Development' as a dominant 'discourse' of western modernity. These views are illustrated in the Fig 1 below,

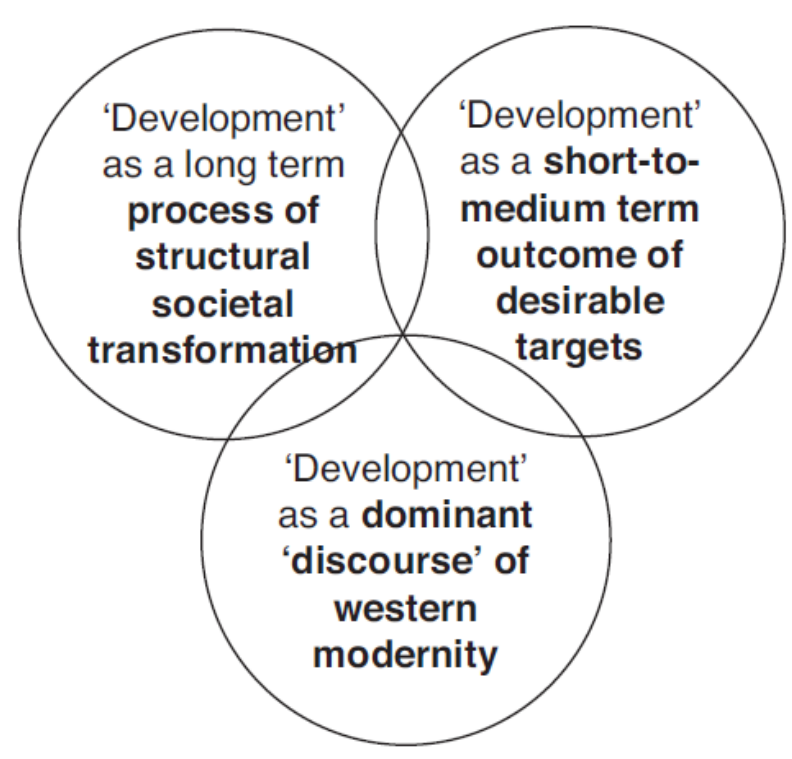

Source: Thomas, [5].

Figure 1. Interlinked definitions of development

According to Thomas, [5] some authors in their attempt to provide a satisfactory definition to the process of development dispute one of the three, some two while others embraces all the three definitions. The definitions of culture and development provide an operational platform where a relationship can be established. Development occurs in a society where people ascribe to certain cultural values thus, adaptation and change of cultural values to suit positive development efforts is required. In reciprocation, community development initiatives must be tailor-made to suit the cultural context within the society. Therefore, the two concepts are not mutually exclusive they are linked and shares the same theatre stage (society) as they take place. Given this background on the nature of culture and development, the research hypothesis will be formulated.

\subsection{Research Working Hypothesis}

The following working hypothesis was designed to guide this research.
- Societal development triggered by enhanced by access to electricity has an effect on the main attributes of culture such as dressing, music, language usage, love relationships and crime.

This working hypothesis will be tested using multiple regression analysis techniques. To achieve this, the paper is structured in five sections which are, introduction, main culture attributes of the indigenous Zimbabwean culture, methodology, results and conclusion. Two provinces of Zimbabwe, Harare province and Manicaland province are sampled. Harare province is relatively more developed than all the provinces in the country will be used as treatment group. In this province which happens to be also the capital city of the country, majority of households and the schools have access to electricity hence, the students watch television and listening to radio and the exposure to such media may leads them to see foreign traits of culture which they may be tempted to incorporate in their culture. In contrast, rural parts Manicaland province where, about 99\% of rural households had no access to electricity will be used as the control group. In this province indigenous Zimbabwean culture is assumed to be still in intact, free external forces of development.

\section{Main Attributes of the Zimbabwean Indigenous Culture}

\subsection{Zimbabwean Culture in the Broad Context of the African Culture}

Zimbabwe is located in Southern Africa, it shares political boundaries with South Africa, Botswana, Mozambique, Malawi and Zambia. Fig 2 below shows the Map of Zimbabwe.

The Southern Africa region was inhabited by the Bantu people who shared the same values and culture before colonialism. It was during the colonial era when political boundaries were inserted resulting in the creation of different countries thereby separating the people. This political demarcation into separate states did not consider the relations which existed among the people. Hence, the Bantu tradition was seriously threatened. Sometimes the Africans were forced to adopt the colonial master's culture (Europeans) who invaded the region and introduced western education and ideas. The ultimate outcome was that, African cultural heritage was slowly diluted and to some extend side-lined, [2]. According to Gbtotokuma, [8 p 21] "the colonialist categorically denied the existence of African cultural values and worse still, taught the Africans themselves to despise them". Related to this is the migration of some South African tribes such as the Sotho and Khosa into Zimbabwe before and during colonial era which resulted in their culture dominating the region they settled. Some of them migrated as wagon drivers for the colonizers and 
settled in the vast Matebeland region which stretches from Beitbridge to Victoria Falls and Binga as indicated on the map, figure 2. This region was inhabited by native tribes such as the "Kalangas" and "Vendas" but they managed to established themselves as the ruling class and submerged the local culture under their Ndebele culture which is more South African than Zimbabwean. However, the process of colonisation can be broadly interpreted by some as modernisation of Africa but, it was done at the expense of the rich African culture that had sustained the people for centuries. Osagie, [9] highlighted that in modernisation theory, a state of development can be reached through a transfer of technological ideas, institutions, values and cultures of the west to the countries in the South. Furthermore, this theory relies on the free trade opinion that, a transfer of modern attitudes reduces the presence of absurd traditional attitudes and fosters an atmosphere for growth in western nations. It must be noted that, free trade being visualised here is one sided osmotic relationship, where the western values are transferred to developing countries and the countries in the west do not partake any of the cultural values of the countries which they colonise,[9].

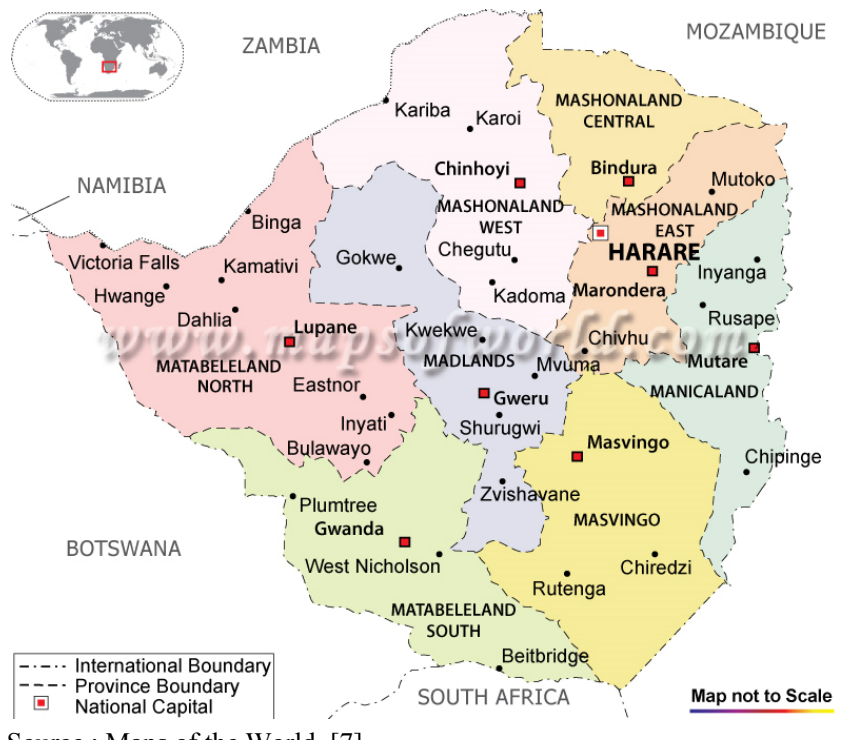

Source : Maps of the World, [7].

Figure 2. Map of Zimbabwe showing the 10 Provinces

Olutayo,[10] proposed that the concept of "Europeanisation" is the implication of this free trade opinion whereby, Europe is perceived to have a higher culture which is mandatory for countries in the South to develop, if this higher culture is rightly adopted, then underdeveloped nations will ultimately become developed. This idea corresponds with concept of summation of acculturation which states that, when an individual moves from one culture to another, there is a gradual superimposition of lifestyle of the second culture on top of the first. In other words, he is still a member to his culture by birth but in many ways, he has become a member of the culture in which he now lives. Nonetheless, there is no full explanation as to whether there is a limit acculturation or what may be called the better brew of culture thus, raising the following question, what if more of the alien culture is consumed and almost nothing of the host culture is left? [4]. To sum up, the concepts of Europeanization and acculturation are essential to tap clues when faced with research task dealing with the interaction of development and indigenous culture.

\subsection{Main Attributes of the Zimbabwean Culture}

\subsubsection{Music as an Attribute of Zimbabwe Culture}

Music in Zimbabwe for the purpose of this research had been broadly classified into traditional, contemporary and foreign music.

\subsubsection{Traditional Music}

Zimbabwe traditional music genre is just as varied as the ethnic groups inhabiting the country because each tribal group has a specific type of traditional music. The Shona tribal groups which constitute $82 \%$ of the population in the country are identified with the following music and dance, "Jerusarema", "Shangara" music and dance and "Mbakumba". The Ndebele tribe which is the second largest group constituting $14 \%$ of the population is associated with "Amantshomane", "Isitshikitsha" traditional music and dance and "Amabhiza" traditional music which is used during their rain-making ceremonies, [11]. Even though the Shona and Ndebele tribes are the majority, some small ethnic groups also practice their traditional music. For instance, the "Shangwe" tribe has "Jichi", traditional music, the "Kalanga" tribe has "Amabhiza" traditional music and the "Ndau" tribe identifies itself with "Muchongoyo" traditional music and dance. Furthermore, the Shona and Ndebele dances have a relationship with the religious and spiritual life of their people. Such as the practice of "mhande" by the "Karanga" people during the "mutoro", a rain-making ritual. In the "Ndebele" tribal group, rain making ceremony is promulgated by a dance called "iHosana" which is rooted the African Traditional Religion, (ATR) where a god in the form of a female spirit medium is believed to bring rain hence, "iHosana" songs are sung to the spirit medium to ask for rains. The names "iHosana" and "Jerusarema" given to these dances reflects culture change where Christian traits in the form the names were introduced in traditional music by colonization. The practice of "isitshikitsha seZangoma", by the "Ndebele" tribe is a sacred traditional music, meant for traditional healers and their apprentices, (Nyathi 2001). Moreover Thramm, [12] stated the therapeutic role played by "dandanda" traditional music and dance, which originates from the "Korekore" tribal group.

\subsection{Contemporary Music}

Contemporary music in Zimbabwe is popularly known as, "Zim dance hall" is literally the music of the moment among 
youth and it is also sung by young artist. The origin of music is rooted in the seventy five percent, (75\%) local content policy introduced by the government of Zimbabwe in 2001 and the subsequent radical shift in radio and television programing. This policy was enshrined in the 2001 broadcasting Services which sought to provide a new regulatory framework to the broadcasting sector after nullifying some sections of 1957 Broadcasting Act which guarantees monopoly to Zimbabwe Broadcasting Cooperation, (ZBC). The modified version of ZBC Act of 2001, Chapter 2.06) section 11 stipulates that, all broadcasters should ensure that, at least seventy five percent of their programming is local content but, it was later pushed to $100 \%$ as the state anti-western imperialism agenda gathered momentum from 2002 onwards, [13,14]. This policy was received with mixed feelings from the public, citizens who were against it argued that it will make it impossible to liberate the air waves. The arts sector which generally welcomed it pointed out that, it will unleash unlimited opportunities for the industry.

As a result, the government high appetite for local content in broadcasting and its intentional effort to play music for hegemonic reasons witnessed the emergency of young musical outfits known in Zimbabwe as "urban grooves" and their type of music is dubbed as "Zim dance hall". This music genre is comprised of albums such as "vanhu vakuru" translated as big man, sung by the artist called Winky D. It describes various experiences occurring in Zimbabwe since the beginning of crisis in 2000. These mushrooming young urban grooves musicians were nourished by foreign music for a long time hence, they emulated western musical icons such as Eminem, Tupac, Shakur, Snoop, Dogg, Michael Jackson, [15]. Therefore, in response to the 75\% local content policy, young musicians composed lyrics blended with western hip hop rhythm, raga beats with local flavors and sung in indigenous language and slang. The rise of Urban grooves music caused controversy in the society, those against them stated that, they lack creativity as seen in their imitation of music icons from the west, poor quality productions, vulgarity and general normlessness. Those in favor posit that, they breathed a new life into the musical industry, they broke the monotony and standardisation of music entrenched by an oligopolistic ownership structure in the music industry. Moreover, some felt that, urban grooves music was an effort to preserve an authentic Zimbabwean cultural identity through the $75 \%$ local content policy. However, this sentiment is contradicted by the way urban groovers sings as echoed in a letter to the state weekly newspaper, Sunday Mail which read,

"It is not debatable that urban grooves imitate their western idols, I have no problem with that but, I would have been happier if they were original. These youngsters should be more discerning in what they imitate. It is not advisable to copy everything. The urban groovers should know that most of the western idols lack morals. In our culture we do not worship sex as these western people do. They sing explicitly about that subject. In our culture we don't use obscene language publicly, but hear what "Maskiri" sings...They should always remember that they are role models for innocent youths. The $75 \%$ local content should be translated to mean 75\% local culture", [14 p 171].

Established and respected artists in the country such as Thomas Mapfumo and Oliver Mutukudzi were strongly convinced that urban grooves musicians lack identity and cultural consciousness, they criticised them for lack of originality and imitating western popular artists. Though the hip hop genre is thought to have originated from Africa as shown in the school of thought where Jimi Hendrix is featured as the first to use African Rhythms from Vodoo, the genre was imported to the western world to the extent that it is now more identified with the western culture than the African culture where it originated thus, in one of his interviews, Thomas Mapfumo asserted that, "he does not tolerate a Zimbabwean artist singing hip hop, it is not their culture, Rap is not Zimbabwean", [15]. Moreover, radio disk jockey Musavengana Nyasha in 2006 once publicly proclaimed that young urban grooves artists are not Zimbabweans, singing western music in native language does not qualify it to be local, the facts that it's a Zimbabwean singing the music also cannot make it local [16]. Despite these critics, defender of urban grooves, producer and co-director of Phathood Entertainment called Jackson Ndoro stated that, urban grooves music is the future of music industry, "....it will be the biggest music genre in Zimbabwe even 20 years from now". In addition, a journalist and music critic named Wonder Guchu stated that, urban grooves genre is still evolving, the artists are still struggling with identity thus, they must be given a chance to master their talent and to stabilise financially, [17].

\subsection{Dressing as an Attribute of Zimbabwe Culture}

Dress is a mode of communication, hence, attention must be paid to message send by a particular dress code, [18]. Zimbabwe's culture and values is reflected in the language of dress, people across gender and age are expected to dress modesty. Dress codes mimicked by all different tribal groups in the country represent the dressing culture of the nation. Each tribal group defines the expectation of men and women dressing. Women are discouraged to dress in a way which exposes their body parts. Zimbabwe's political leaders have repeatedly castigated dressing in see through, miniskirts and tight dressing. In the same manner, youth subculture of dressing which expose the midriff and upper chest had been denounced. It is a taboo as prescribed by the indigenous Zimbabwean culture. Modest in dressing is highly valued thus, women are not supposed to move around exposing their body parts, [19]. In addition, Women dressing must be practical, comfortable and easy to wear. It has to place minimum emphasis on attracting opposite sex. Exposing a women's body by wearing clothes which are sleeveless, too tight or too small is viewed as a breach of norms, [20]. 


\subsection{Crime Attribute and the Zimbabwean Culture}

Murder, indecent sexual assault, robbery and drug use crime will be discussed showing their nature and prevalence in communities where interviewed youth in High Schools live. Though Zimbabwean communities are generally peace loving, some criminal activities exists giving rise to some forms of conflicts. Severe and mild punitive measures exist in the criminal justice system of the country and they are applied based on the degree of the offense. The judicial procedure to handle crime is different in traditional communities in rural areas and communities in urban settings. In the rural areas, traditional courts are under the jurisdiction of village heads at lower level and the Chief of an area represent the highest judicial office, he presides over all unresolved cases at village level. In developed urban settings criminal activities are handled by the conventional judicial process through the magistrate's courts, high court and the Supreme Court depending on the complexity of the crime.

\section{6. Marriage Unions in Zimbabwe}

The Zimbabwean indigenous culture requires payment of bride price "roora" as the basis of marriage and official grounds of conjugal rights to partners. Despite the continuing emphasis on bride price payments ethnographic literature shows several types of unions exist and they deviate from the normative "roora" or bride price payment marriage, [21]. Decline of bride price payment marriage and the rise of informal types have been observed among educated segments of urban dwellers. This is attributed to gradual collapse of men influence due to increasing number of women who are becoming breadwinners, professionals, better educated and wealthy. Instead of contracting formal marriage unions these women opt for cohabitation or lovers who do not live with them because this situation gives them freedom. Despite these developments, the Zimbabwean indigenous culture considers bride price payment "roora" as a noble custom which functions as a safeguard against marital dissolution because bride price generally needs to be paid back upon divorce, [22, 23]. Bride price payment or "roora" gives man the custody of children resulting from the union and rights in genetricem and uxorem. [24].

\section{Methodology}

An identical survey instrument was used to collect and analyse data from schools in the developed Harare Province and from under developed schools in Manicaland Province. Permission to conduct this study was sought and granted at the Head Office for Zimbabwe Ministry of Education Sports and Culture in a letter with reference number C/426/3 Harare. Using this authorization letter, at district level, District Education Officers instructed all the headmasters of selected schools to allow the research team to conduct the survey without interrupting the school curriculum. A total of 400 youth in high schools comprised of 200 from Harare province and 200 from Manicaland province participated in this research. Their age range was between 18 and 21. Data collection was conducted by a team of 6 interviewers over a period of 14 days from 17-30 May 2015. Before the final questionnaire was administered in sampled schools, a pilot survey was conducted on two schools in Harare Province. Responses given during piloting led to the adjustment of the survey questionnaire in order to make all questions relevant to the study and the context of the targeted schools. The adjusted survey questionnaire was the final survey instrument used for data collection in all schools targeted by this research.

\subsection{Data Collection Tools}

This research was conducted in a participatory manner, obtained data was analyzed quantitatively. The following data collection tools were used.

\subsubsection{Survey Questionnaire}

All 400 students who participated in the survey research had to answer a questionnaire with 16 questions and 21 variables and this took on average 10-12 minutes per student.

\subsubsection{Informal Interviews}

Apart from the main face to face interviews with students on each school visited, informal interviews were also conducted to some randomly selected students and teachers from the targeted schools.

\subsection{Data Processing and Analysis}

After the survey was conducted, data cleaning was on each questionnaire, mistakes, outliers and other missing information was noted and corrected. When all the questionnaires were cleaned the information was entered on Stata. In total the Stata dataset produced was composed of 21 variables and 400 observations. The variables were as follow as, Traditional music, Contemporary music, Foreign Music, Love relation, relationships, Hugging, Kissing, Language use with elders, Language use with youth, Robbery, Indecent assault, Murder, Drugs, Access, Age, Gender, Income level, Family size, breadwinner, Head of the household, Income source, Income level and Distance. 


\section{Results}

Table 1. Statistical Summary of variables included in the dataset on interaction of development and culture.

\begin{tabular}{|c|c|c|c|c|c|}
\hline Variable & $\mathrm{Obs}$ & Mean & Std. Dev. & Min & $\operatorname{Max}$ \\
\hline TradMusic & 400 & 1.2975 & .7213144 & 1 & 4 \\
\hline ContMusic & 400 & 2.9575 & 1.085652 & 1 & 4 \\
\hline ForeMusic & 400 & 2.76 & 1.170823 & 1 & 4 \\
\hline Dressing & 400 & 3.35 & 1.051315 & 0 & 4 \\
\hline Inrelation & 400 & .4525 & .498362 & 0 & 1 \\
\hline Hugging & 400 & .5175 & .5003194 & 0 & 1 \\
\hline Kissing & 400 & .7925 & .4060245 & 0 & 1 \\
\hline Language $\mathrm{E}$ & 400 & 1.7325 & .9397615 & 1 & 3 \\
\hline LanguageY & 400 & 2.5 & .686424 & 1 & 3 \\
\hline Robbery & 400 & 2.135 & .8476859 & 1 & 4 \\
\hline IndescentA & 400 & 1.4725 & .6365979 & 1 & 4 \\
\hline Murder & 400 & 1.44 & .657633 & 1 & 4 \\
\hline Drugs & 400 & 2.42 & 1.047063 & 1 & 4 \\
\hline Access & 400 & .5025 & .5006199 & 0 & 1 \\
\hline Age & 400 & 2.995 & .3468079 & 0 & 4 \\
\hline Gender & 400 & .5125 & .5004697 & 0 & 1 \\
\hline IncomeLevel & 400 & 2.42 & 1.136587 & 1 & 4 \\
\hline FamilySize & 400 & 2.3075 & .7677352 & 1 & 4 \\
\hline BreadWinner & 400 & 1.525 & .7353413 & 1 & 3 \\
\hline HHHead & 400 & 1.535 & .731514 & 1 & 3 \\
\hline Incomes & 400 & 2.9375 & .9304613 & 1 & 6 \\
\hline Distance & 400 & 2.995 & 1.721157 & 1 & 6 \\
\hline Province & 400 & .5025 & .5006199 & 0 & 1 \\
\hline
\end{tabular}

Table 1 above is a statistical summary of the 21 variables across 400 observations. Gathered information on each variable was entered on stata version 12 and a dataset called interaction of development and culture was produced. The data shows the number of observations, mean, standard deviation, minimum and maximum categories in each variable. Various statistical analysis including multiple logistics regression techniques were conducted produce models for hugging and kissing as well as to analyse outcome of each attribute.

\subsection{Logistic Regression Models and Statistical Analysis of Attributes of Culture}

Table 2. Logistic regression model for kissing aspect in a romantic love relationship

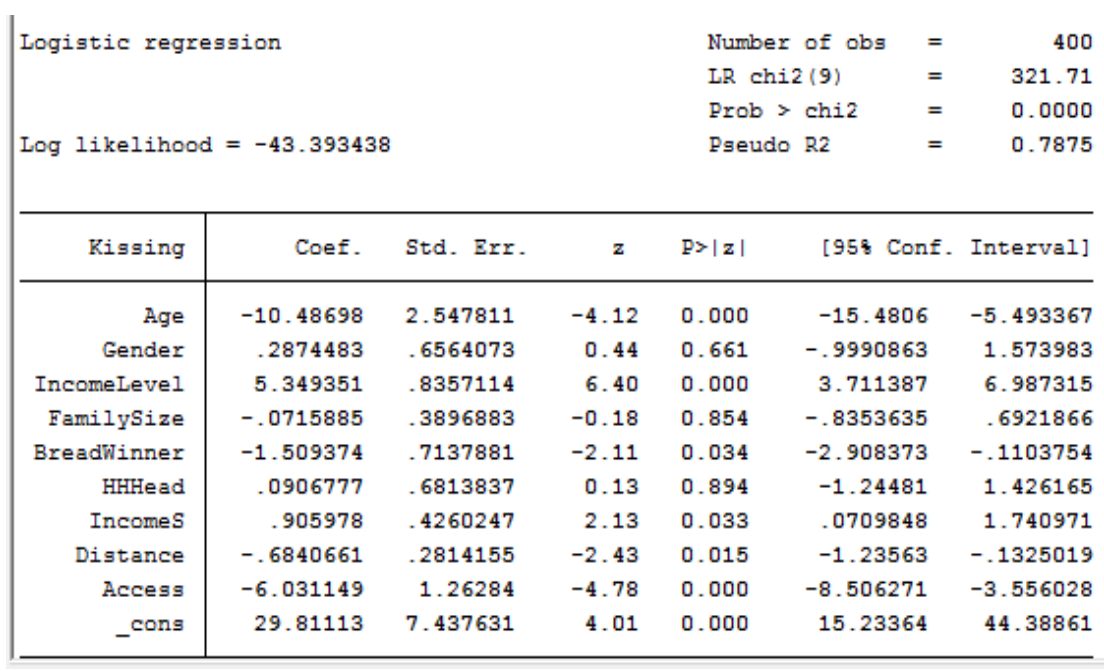


In this logit model Kissing is the dependant variable which is being regressed with nine regressors, and six of the regressors which are age, income level, breadwinner, income source, distance and Access are significant hence, explains the model. For instance, the variable Access has a coefficient value of $-6,031149$. This means that for youth in romantic love relationships in rural parts of Manicaland province, lack of access to electricity as an inhibiting factor to development correlate to the reduction of kissing in a romantic love relationship by a factor of - 6,03 units for youth in high schools in rural parts of Manicaland province when compared to youth in high schools of Harare province.

Table 3. Students in romantic love relationships in the provinces

\begin{tabular}{|r|rrr} 
trab Inrelation & & & \\
Inrelation & Freq. & Percent & Cum. \\
\hline 0 & 118 & 59.00 & 59.00 \\
1 & 82 & 41.00 & 100.00 \\
\hline Total & 200 & 100.00 &
\end{tabular}

\section{Key}

- $\quad 0$ Students in a romantic love relationship in Harare Province

- 1 Students in a romantic love relationship in Manicaland province

\section{Outcome}

- $\quad 59 \%$ of students in Harare province are in a romantic love relationship

- $41 \%$ of students in Manicaland province are in a romantic love relationship

Table 4. Number of students in Harare province who kiss and don't kiss their partners in their love relationships

\begin{tabular}{|c|c|c|c|}
\hline Kissing & Freq. & Percent & Cum. \\
\hline 0 & 83 & 20.75 & 20.75 \\
\hline 1 & 317 & 79.25 & 100.00 \\
\hline Total & 400 & 100.00 & \\
\hline \multicolumn{4}{|c|}{$\begin{array}{l}\text { keep if Province }=0 \\
\text { (200 observations deleted) }\end{array}$} \\
\hline \multicolumn{4}{|c|}{. tab Kissing } \\
\hline Kissing & Freq - & Percent & Cum. \\
\hline 0 & 75 & 37.50 & 37.50 \\
\hline 1 & 125 & 62.50 & 100.00 \\
\hline Total & 200 & 100.00 & \\
\hline
\end{tabular}

Key

- 0 Students who do not kiss their partners

- 1 Students who kiss their partners

Outcome

- $37,5 \%$ of the students in a romantic love relationship do not kiss their partners

- $63 \%$ of the students in a romantic love relationship do kiss their partners 
Table 5. Number of students in Manicaland province who kiss and don't kiss their partners in love relationships

\begin{tabular}{|c|c|c|c|}
\hline Kissing & Freq. & Percent & Cum. \\
\hline 0 & 83 & 20.75 & 20.75 \\
\hline 1 & 317 & 79.25 & 100.00 \\
\hline Total & 400 & 100.00 & \\
\hline \multicolumn{4}{|c|}{ - keep if Province $=1$} \\
\hline \multicolumn{4}{|c|}{. tab Kissing } \\
\hline Kissing & Freq. & Percent & Cum. \\
\hline 0 & 8 & 4.00 & 4.00 \\
\hline 1 & 192 & 96.00 & 100.00 \\
\hline Total & 200 & 100.00 & \\
\hline
\end{tabular}

Key

- 0 Students who do kiss their partners

- 1 Students who not kiss their partners

Outcome

- $\quad 4 \%$ of the students in a romantic love relationship do kiss their partners

- $96 \%$ of the students in a romantic love relationship do not kiss their partners

Table 6. Logistic regression model for hugging aspect in romantic love relationships

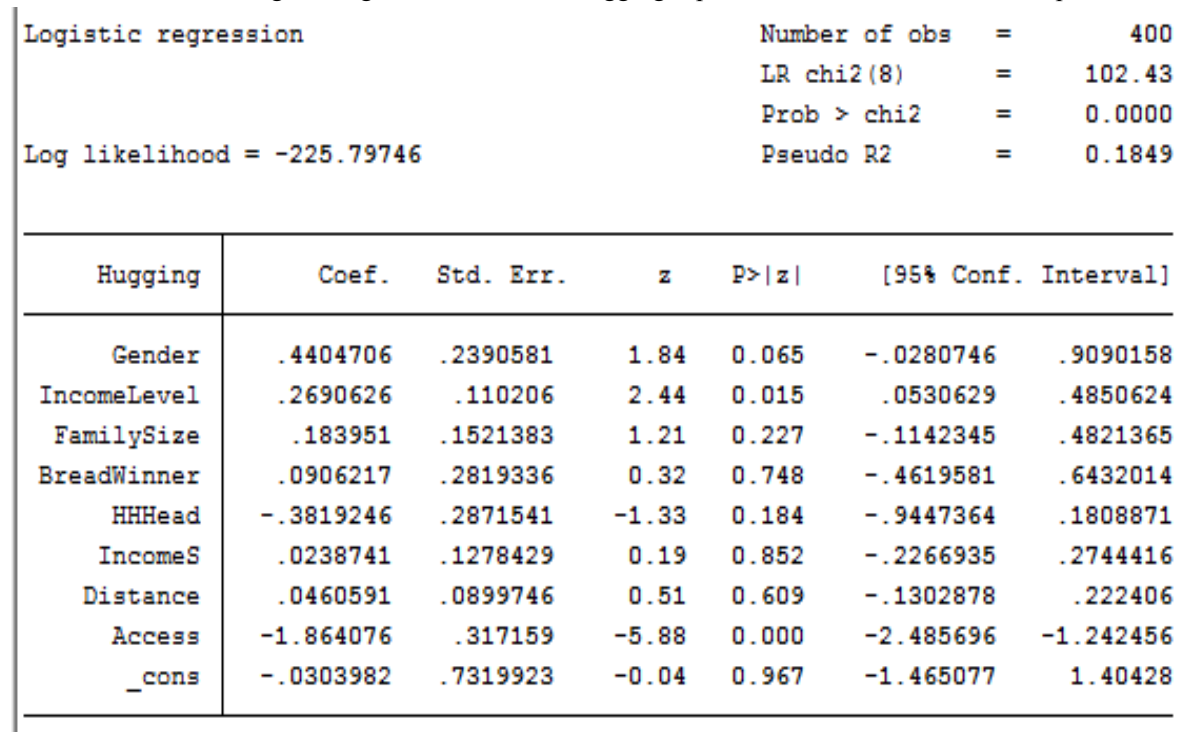

In this logit model hugging is the dependant variable which is being regressed with nine regressors. Two of the regressors income level and Access are significant hence, have huge explanatory power to the dependant variable hugging. For example, the variable Access has a coefficient of $-1,834076$. This means that for youth in romantic love relationships in rural parts of Manicaland province, lack of access to electricity as an inhibiting factor to development correlate to the reduction of hugging habits in a romantic love relationship by a factor of $-1,83$ units for youth in high schools found rural parts of Manicaland province compared to youth in high schools for Harare province. 
Table 7. Results on provincial comparisons of attributes

\begin{tabular}{|c|c|c|c|}
\hline & Culture attribute & Students in Harare Province & Students in Manicaland Province \\
\hline 1 & Love relationships & $59 \%$ of students are in a romantic love relationship. & $51 \%$ of students are in a romantic love relationship. \\
\hline 2 & Hugging and kissing & $\begin{array}{l}37 \% \text { of students in love relationship hug and kiss their } \\
\text { partners in public }\end{array}$ & $\begin{array}{l}4 \% \text { students in love relationship hug and kiss their } \\
\text { partners in public }\end{array}$ \\
\hline 3 & Dressing in mini skirts & $\begin{array}{l}24 \% \text { of female students wear miniskirts as preferred } \\
\text { casual dressing. }\end{array}$ & $\begin{array}{l}22 \% \text { of female students wear miniskirts as preferred } \\
\text { casual dressing. }\end{array}$ \\
\hline 4 & Dressing in long dress & $\begin{array}{l}45 \% \text { female students wear long skirts as preferred } \\
\text { casual dressing }\end{array}$ & $\begin{array}{l}49 \% \text { of female students wear long skirts as preferred } \\
\text { casual dressing. }\end{array}$ \\
\hline 5 & Traditional music & $\begin{array}{l}\text { Among the assessed } 3 \text { types of genre, } \\
\checkmark \quad 35 \% \text { of students had no interest in listening to } \\
\text { traditional music. } \\
\checkmark \quad 36 \% \text { expressed interest in traditional music and, } \\
\checkmark \quad 29 \% \text { make it their main form of entertainment. }\end{array}$ & $\begin{array}{l}\checkmark \text { of students had no interest in listening to } \\
\text { traditional music. } \\
87 \% \text { of the students expressed interest to listen to } \\
\text { traditional music half the time of their music } \\
\text { entertainment and } \\
\checkmark \quad \begin{array}{l}\text { Only } 12 \% \text { takes this genre as their main form of } \\
\text { entertainment. }\end{array}\end{array}$ \\
\hline 6 & Contemporary music & $\begin{array}{l}\text { Among the assessed } 3 \text { types of genre } \\
\checkmark \quad 35 \% \text { of students had no interest in listening to } \\
\text { contemporary music, } \\
\checkmark \quad 56 \% \text { expressed interest and listen to it half the } \\
\quad \text { time of their entertainment and } \\
\checkmark \quad 9 \% \text { make it their main form of entertainment. }\end{array}$ & $\begin{array}{l}\checkmark \quad 11 \% \text { of students had no interest in listening to } \\
\text { contemporary music } \\
\quad 30 \% \text { expressed interest to listen to it half the time } \\
\text { of their music entertainment and } \\
\checkmark 4 \% \text { are committed to it as their main form of } \\
\text { entertainment }\end{array}$ \\
\hline 7 & Foreign music & $\begin{array}{l}\text { Among the assessed } 3 \text { types of genre } \\
\checkmark \quad 8 \% \text { of students had no interest in listening to } \\
\text { foreign music, } \\
\checkmark \quad 36 \% \text { listen to it half the time of their music } \\
\text { entertainment and } \\
\checkmark \quad 56 \% \text { make it their main form of internment }\end{array}$ & $\begin{array}{l}\checkmark \quad 48 \% \text { of students had no interest in listening to } \\
\text { foreign music } \\
45 \% \text { expressed interest in listening to it half the } \\
\text { time of their music entertainment and } \\
\quad 10 \% \text { make it their main form of internment. }\end{array}$ \\
\hline 8 & $\begin{array}{l}\text { Youth Language } \\
\text { usage with Elders }\end{array}$ & $\begin{array}{ll}\checkmark & 44 \% \text { of students use formal language when } \\
& \text { communicating with elders, } \\
\checkmark & 6 \% \text { use colloquial language and } \\
\checkmark & 50 \% \text { use mixed language. }\end{array}$ & $\begin{array}{ll}\checkmark & 78 \% \text { of students use formal language when } \\
\text { communicating with elders, } \\
\checkmark \\
\checkmark \\
\checkmark \% \text { use colloquial language and } \\
18 \% \text { use mixed language. }\end{array}$ \\
\hline 9 & $\begin{array}{l}\text { Youth Language } \\
\text { usage among their } \\
\text { peers }\end{array}$ & $\begin{array}{ll}\checkmark & 19 \% \text { of students use formal language when } \\
& \text { communicating among with peers, } \\
\checkmark & 34 \% \text { use colloquial language and } \\
\checkmark & 47 \% \text { use mixed language. }\end{array}$ & $\begin{array}{ll}\checkmark & 18 \% \text { of students use formal language when } \\
\text { communicating with peers, } \\
\checkmark \\
\checkmark \\
\quad 34 \% \text { use colloquial language and } \\
48 \% \text { use mixed language. }\end{array}$ \\
\hline 10 & Robbery & $\begin{array}{l}\text { Students were asked on a scale of } 1-10 \text {, how you rate } \\
\text { robbery cases committed in your neighborhood, } \\
\checkmark \quad 24 \% \text { of students stated that murder cases occur } \\
\text { half the time or at } 5 \text { point of the scale. }\end{array}$ & $\begin{array}{l}\text { Students were asked on a scale of } 1-10 \text {, how you rate } \\
\text { robbery cases committed in your neighborhood, } \\
\checkmark \quad 20 \% \text { of students stated that murder cases occurs } \\
\text { half the time or at } 5 \text { point the scale when the same } \\
\text { question was asked. }\end{array}$ \\
\hline 11 & Indecent Assault & $\begin{array}{l}\text { Students were asked on a scale of } 1-10 \text {, how you rate } \\
\text { indecent assault cases committed in your } \\
\text { neighborhood, } \\
\checkmark \quad 9 \% \text { cases of indecent assault are reported half } \\
\text { the time or at } 5 \text { point the scale. }\end{array}$ & $\begin{array}{l}\text { Students were asked on a scale of } 1-10 \text {, how you rate } \\
\text { indecent assault cases committed in your neighborhood } \\
\checkmark \quad 38 \% \text { cases are reported half the time or at } 5 \text { point } \\
\text { the scale when the same question was asked. }\end{array}$ \\
\hline 12 & Drug usage & $\begin{array}{l}\text { Students were asked on a scale of } 1-10 \text {, how you rate } \\
\text { drug use cases committed in your neighborhood, } \\
\checkmark \quad 32 \% \text { cases of drug usage are reported half the } \\
\text { time or at } 5 \text { point the scale. }\end{array}$ & $\begin{array}{l}\text { Students were asked on a scale of } 1-10 \text {, how you rate } \\
\text { drug use cases committed in your neighborhood, } \\
\checkmark \quad 39 \% \text { of drug use cases are reported half the time or } \\
\text { at } 5 \text { point the scale when the same question was } \\
\text { asked. }\end{array}$ \\
\hline
\end{tabular}

\subsection{Provincial Comparisons of Attributes}

Analysis of results after administrating an identical survey instrument in the two provinces is shown in table 7. The table shows from the left side the assessed attributes of culture numbered from item 1 to 12 and the outcome of each attribute for high school students in Harare province and the targeted rural parts of Manicaland province. The underlying causes of differences seen are explained in level of culture change emanating from level of development within a province.

\subsection{Discussion of Results on Attributes of Culture}

\subsubsection{Relationship Attribute}

In terms of romantic love relationships among students, table 7 item 1 and 2 states that Harare province has $59 \%$ of students in Harare province are romantic love relationships while Manicaland province has $51 \%$. Moreover, $37 \%$ of students in Harare who are in love relationships hug and kiss their partners in open spaces in view of the public which is a bigger number when compared to Manicaland province where $4 \%$ hug and kiss in public spheres. These findings make it evident that the prescriptions on indigenous culture 
of Zimbabwe in terms of handling love relationship had been eroded by culture change in Harare province but it is still intact in Manicaland province. In the traditional Zimbabwean culture it is considered immoral, a shame and lack respect for young unmarried people to be seen hugging and kissing in especially in public places but this behavior is already surfacing in Harare province. One contributing factor to this is income levels for parents of students in Harare which are higher compared to that of their counterparts in rural Manicaland province. This high income enables their children to be mobile. They can travel to different entertainment spots in the city, out of their neighborhood where they are not known hence, become more flexible to hug and kiss their partners. This degree of mobility does not exist among students in rural Manicaland province. They are largely within the confines of their communities where they are known by the neighborhood hence, there is deliberate effort to hide their relationships. Expressing love by hugging and kissing in public makes them subjects of criticism and they can be reported to their parents for disciplinary measures. Furthermore, a number of students in Harare province stated that their household heads are single parents. In community children of single parents are viewed as lacking social control and adequate parental guidance. To a certain extent they model the behavior from their parent who at times may change sexual partners. In addition, exposure to satellite television, and access to social media through smart phones also contribute significantly to their behavior in handling romantic love relationships.

\subsubsection{Dressing Attribute}

As shown in table 7 item 3 and 4, a bigger percentages of students wearing miniskirts and less percentage wearing long skirts in the Harare province than rural parts of Manicaland province. Harare being the developed province has $24 \%$ of female students who wear miniskirts and $42 \%$ wearing long skirts. On the other hand Manicaland province has $22 \%$ wearing miniskirts and $49 \%$ wearing long skirts. This outcome portrays that the culture of female dressing in Harare province has deviated from the approved code for women which is still dominant in Manicaland province. More girls wearing miniskirts in Harare than Manicaland can be attributed more to culture change through media exposure than lack of shops to buy miniskirts since plenty flea markets are available with cheap second hand clothes imported from abroad through the Port of Beira in Mozambique An additional factor is that in Zimbabwe under development is synonymous with conservatism hence, the girls in the underdeveloped parts Manicaland turn to conserve their culture and shun away from dressing in miniskirts which are alien to their culture. Berns, [19] stated that dress can be used to define culture since it communicates affiliation, values, and attitudes and beliefs. Zimbabwe culture defines a dress code for women, which is compatible with the norms and values of the Africa society. Women are expected to wear dresses, blouses, skirts and others forms of dress which are not alien to cultural values but in Harare modernity has crept in causing changes in the way ladies dress. A miniskirt is a short dress with hemline positioned on top of the knees or half way of the thighs. Wearing of miniskirts, trousers and any form of dressing which reveals body parts is not acceptable by Zimbabwean culture. The rise of hemlines, the wearing of tights and see-through is becoming more common in Harare province and this became more common in 2011 in Zimbabwe [25]. Now miniskirts are being seen worn over trousers and jeans or with leggings that provides coverage of each leg from the knee which is a practice incompatible with the Zimbabwean culture. One can attribute these changes to but given the current context of country emigration is not playing a role as it is a bad destination for migrants rather it is facing net migration for economic reasons in neighboring countries and abroad therefore, media exposure is the main factor to explain girls dressing in Harare province. This culture change in ladies dressing is becoming a major concern for the conservative members of the Zimbabwean culture as can be seen in one of educationist called Kundiona who recently proposed to ban wearing of miniskirts by female students in schools as this practice disturbs the male students and male teachers, [26].

\subsubsection{Traditional Music Attribute}

According to table 7 item 5, Harare province has 35\% of the students who do not like to listen to traditional music, they have no interest at all in this type of music and $36 \%$ expressed in traditional music while $29 \%$ of the students were committed to make traditional music as their main form of entertainment. In Manicaland province $1 \%$ of the students do not like to listen to traditional music, they have no interest at all in this type of music and $87 \%$ expressed interest in traditional music while $12 \%$ of the students were committed to make it their main form of entertainment. These results show that lack of interest in traditional music is common in both provinces. The music faces an unhealthy future as most young people now shun it in favor of contemporary music which is also dubbed as "Zim Dancehall" and foreign music. Traditional music by its virtue of being an effective platform where culture is transmitted inter and intra-generations needs to be safeguarded by innovative measures from the government supported by the private sector. The government through the National Arts Culture of Zimbabwe needs to double its effort and incentivize the private sector to increase their Corporate Social Responsibility, (CSR) budgets in supporting cultural events. It is unfortunate that traditional dance as fostered by the Ministry of Primary and Secondary Education has been restricted largely to competitions, [27 p 1]. The "Jikinya" dance festival confined to primary schools and "Chibuku Neshamwari" traditional dance competition open to anyone above 18 are two notable traditional music dancing completion. The aim of the festivals is to encourage people to appreciate indigenous traditional dances. Although these competitions are the only two reliable platforms for traditional music, they remain isolated events with no other 
mechanisms set up to promote the music, [27]. Such a situation points to traditional music in Zimbabwe as serving for the purpose of officialdom (used for official events) similar to Kenyan situation before the advent of ethnic nights in entertainment spots found in cities where traditional music out played other types. The music needs to be liberated from officialdom and consumed by masses, unless this happens, this genre remains at the point of death where resuscitation if not urgently implemented might not yield any result, [28].

\subsubsection{Contemporary Music or "Zim dance hall music"}

Considering contemporary music, table 7 item 6 shows that, in Harare province $35 \%$ of the students do not listen to contemporary music, they have no interest at all in this type of music and $56 \%$ expressed high interest in contemporary music while $9 \%$ of the students were committed to make it their main form of entertainment. On the other hand in Manicaland province, $11 \%$ of the students do not listen to contemporary music, they have no interest at all in this type of music and $30 \%$ expressed interest in contemporary music while $64 \%$ of the students were committed to make it their main form of entertainment. In every aspect of live people want to live the contemporary or current times as it captures the essence of their existence. This can be the plausible explanation to the reason why interviewed youth where highly interested in contemporary music than traditional and foreign music. In the same way culture should not be rigid but must change and adapt to the contemporary time for the benefit of its people. The rise of contemporary music in the form of "Zim dance hall" created controversy in the country because the artist comprised of the young generations and their music lyrics were alien to the traditional culture of the country. Resistance to this genre came from most established artists and some conservative music addicts. However, despite the critics of contemporary music this research has established that it has many supporters among the youth in urban and in rural areas. This massive support by the youth explains why, Oliver Mutukudzi who is a respected prominent musician icon in Zimbabwe who was initially opposed to this genre eventually appeared in public media to officially recognise contemporary music [29].

\subsubsection{Foreign Music}

According to table 7 item, in Harare province $8 \%$ of the students do not like to listen to foreign music, they have no interest at all in this type of music and 36\% expressed interest in foreign music $56 \%$ of the students were committed to make it their main form of entertainment. On the other hand, in Manicaland, $48 \%$ of the students do not listen to foreign music, they have no interest at all in this type of music and $45 \%$ expressed interest in foreign music while $10 \%$ of the students were committed to make it their main form of entertainment. This outcome further highlights the influence of access to electricity which had enabled many households in Harare province to acquire television sets and are connected to digital satellite television where their children watch foreign broadcast channels. In addition, some of the children have smart phones with access to internet and social media where they listen to foreign music.

\subsection{Language Usage and Proxemics (distance / space between two people when communicating)}

\subsubsection{Youth Language with Their Elders}

Table 7 item 8 shows that, $44 \%$ of students in Harare province use formal language when communicating with their elders while $6 \%$ use colloquial language and $50 \%$ use mixed language. On the contrary in Manicaland province, $78 \%$ of students in Harare province use formal language when communicating with their elders while $4 \%$ use colloquial language and $18 \%$ use mixed language. The notable outcome in these figures is that in Manicaland province youth use informal language when they are communicating among themselves but when communicating with adults they switch to formal language only. The reason why many youth in Harare use mixed and colloquial language than in Manicaland was explained by some students to be due to the nature of their province that happens to be a cosmopolitan capital city inhabited by people from various ethnic backgrounds with different languages and dialects. Some dialects and languages are considered inferior, thus use of colloquial language absorbs dialectal differences and unify people under one language. Moreover, some students interviewed highlighted that the tendency to switch from formal to colloquial and mixed language in conversation is a sign of sophistication, they admired this behavior. However, use of colloquial and mixed language when communicating with parents and other elders in the community is an epitome of disrespect and infidelity to the traditional Zimbabwean cultural norms.

\subsubsection{Youth Language Use among Themselves}

As indicated by table 7 item 9,19\% of students in Harare province use formal language when communicating among themselves while $34 \%$ use colloquial language and $47 \%$ use mixed language. On the contrary, in Manicaland province $18 \%$ of students in Harare province use formal language when communicating with their elders while $34 \%$ use colloquial language and $46 \%$ use mixed language. This outcome shows that use from both province are use more colloquial and mixed language when conversing with peers. This is a fashionable form of language for the youth but, need not to be used to elders as shown by Manicaland use youth who makes a deliberate effort to eliminate it when interacting with their elders.

\section{Crime Attribute}

\subsubsection{Robbery, indecent assault and drug abuse criminal cases}

Three aspects of crime, robbery, indecent assault and drug 
abuse were asked to interviewed students in both provinces. The question on this attribute was structured as follow as, "On a scale of 1-10 give an estimate of robbery, indecent assault and drug abuse cases which were committed in your neighborhood that reported to law enforcement agencies". The outcome according to table 7 item 10,12 and 12 is that $24 \%$ of students in Harare province stated that robbery cases occur half the time or at 5 point of the scale while in Manicaland province it is $20 \%$. On indecent assault, $9 \%$ of students in Harare province stated it occurs half the time or at 5 point of the scale while in Manicaland province it is $38 \%$. Furthermore, on drug abuse $32 \%$ of students in Harare province and 39\% in Manicaland province stated these cases occur half the time or at 5 point of the scale. When looking at robbery criminal cases, the figures show that more incidences are reported in Harare province which can be explained by soaring levels of unemployment and poverty. Moreover, the existence of a ready market for electronic gadgets and other household equipment in Harare province fuels incidences of house breaking and other forms of robbery. In some cases robbery cases leads to murder, one of the interviewees remarked, "here in Harare if a robbery victim try to resist he or she can end up being killed therefore, for the sake of your life it is better to corporate with the demands of robbers" In contrary, in the rural parts of Manicaland province there is no ready market for stolen items and households are sparsely populated hence, if one steals something there is need to carry it over a long distance which increases the chances of being caught. These factors contribute to the reduction in robbery criminal cases in the province. In terms of indecent assault, many of these cases were reported in the underdeveloped parts of Manicaland province than in Harare province. Interviewees highlighted some dominant cultural and religious practices which condone early child marriages and the girl child failure to continue with education because of high fees and levies charged by some schools. Moreover, a greater percentage of drug abuses criminal cases was found in underdeveloped rural parts of Manicaland province because lack of entertainment thus, people end up resorting to drugs especially marijuana which locally grown and chances of being arrested are slim because police presence is rare and sometimes nonexistent.

\subsection{Link with Other Studies}

Similar studies on the impact of development on crime and music as attributes of culture includes a case study by De Mello \& Zilberman, [30] which investigated cities in the State of Sao Paulo and the affluent crime infested state of Brazil. Results indicated that crime significantly influences economic decisions regarding saving. Estimates indicated that property crime variation explains $2,3 \%$ of variations in aggregate savings between 1999-2004. Furthermore, Van Dijck, [31] international study on the effects of crime and economic development where a composite index of organised crime for 150 countries was constructed. Results highlighted that crime and corruption as contributors to massive weakening of economic growth and institutional systems which are mandatory long term economic growth.

Turning to music, ethnic nights in Kenya such as "Mugiithi night" meant for Kikuyu tribe, "Mulembe night" meant for the Luhya tribe, "Kilimbi night" meant for Kamba tribe and "Ramogi night" meant for the Luo tribe resulted in rural urban migration of traditional music which is the massive movement of traditional music from rural areas to cities and became one of the main form of entertainment and overtook foreign music. This resulted in traditional music being freed from officialdom purposes where the music was mainly tied to official events such as drama festivals and formal political celebrations. Nonetheless, through the invention of ethnic nights in Kenyan urban areas, the music gained popularity and dominated foreign and other western music in entertainment scenes, [32]. In contrast, this paper had shown the opposite in Zimbabwe because traditional music is slowly dying and something urgent has to be done sustain it.

\subsection{Conclusions}

Table 8 shows attributes of culture and the outcome of the working hypothesis. Failure to reject the working hypothesis means that development has no effect on the attribute while rejecting the working hypothesis means development has an effect.

Table 8. Attributes and outcome of working hypothesis

\begin{tabular}{|c|c|c|}
\hline & Culture attribute & $\begin{array}{c}\text { Outcome on the working } \\
\text { Hypothesis }\end{array}$ \\
\hline 1 & Love relationships & Rejected \\
\hline 2 & Dressing & Rejected \\
\hline 3 & Traditional music & Fail to reject \\
\hline 4 & Contemporary music & Fail to reject \\
\hline 5 & Foreign music & Rejected \\
\hline 6 & Language use with elders & Rejected \\
\hline 7 & Language use among youth & Fail to reject \\
\hline 8 & Robbery cases & Rejected \\
\hline 9 & Indecent assault cases & Fail to reject \\
\hline 10 & Drug use cases & Rejected \\
\hline
\end{tabular}

As indicated in table 8, the implication of rejecting the working hypothesis for robbery and drug use is that these criminal cases are more pronounce in the developed Harare province. Such an outcome supports the modernisation theory of explaining crime where Robert, [33] postulates that as societies move from traditional to modernity, overall crime levels will raise and the mix of crimes will change in response to new social and economic conditions. Moreover, the falling apart in patterns of traditional authority and the mushrooming of chaos associated with economic hazards of urban life style leads to uncertainty, normlessness and 
criminal activities. Accordingly, the increase in robbery and drug abuse crimes in the developed Harare province when compared to rural parts of Manicaland province can be interpreted as an indicator of modernity. Conclusively, this paper contributes to scientific research by providing a primary research supported with statistical data. Particularly in Zimbabwe where the research was conducted, statistical data is hardly available thus, this paper which is based on collecting primary data managed to generate information which can be used by other researchers as secondary data source.

\section{REFERENCES}

[1] Shoremi. The science of Society, A Sociological introduction. In The Concept of Culture (pp. 88-105). Ogun State: Center for sandwich Programmes (ESAP), Ogun State University, Ago-Iwoyi; 1999 .

[2] Ifenyinwa, A., \& Mbakogu, A. Is There Really a relationship Between Culture and Development. Anthropology 2004 (6) $37-46$.

[3] Oyeneye, O., \& Shoremi, M. (1985). The Concept of Culture and Nigerian Society. In Nigeria Life and Culture, A book of Readings. Ogun State: Ogun State University, Ago-Iwoyi; 1985 p. 1-13).

[4] Dabaghian, J. Mirrow of Man, Readings in Sociology and Literiture. Toronto, Canada: Little Brown and Company Limited; 1970 p 103

[5] Thomas, A. The study of deveopment. paper prepared for DSA Annual Conference. London: Church House; 2004.

[6] Chambers, R. Ideas for Development. IDS Working Paper. Sussex: IDS; 2004.

[7] Maps of the World. [Internet] (2012, May 11). Political map of Zimbabwe. Retrieved April 20, 2016, from mapsofworld.com:

http://www.mapsofworld.com/zimbabwe/zimbabwe-political -map.html

[8] Gbtotokuma, Z. Culture Identity and Underdevelopment in Sub-Saharan Africa. Voices from Africa, 1996; 17-29.

[9] Osagie, S. The Concept of Material Culture and Contemporary Issues in Nigeria. In Nigerian Life and Culture,A Book of Readings Ogun State: Ogun State University, 1985 p 117-138.

[10] Olutayo, O. Gender Society and Development. In Nigerian Life and Culture, A Book of Readings. Ogun State: Ogun State University, Ogo-Iwoyi, 1985 p 190-208.

[11] Asante, K. Zimbabwe Dance: Rhythmic Forces, Ancestral Voices-An Aesthetic Analysis. Trenton: African World Press, Inc, 2000.

[12] Thramm. Therapeutic Efficacy of Music Making: Neglected Experience of Integral Importance Process". Yearbook of Traditional Music 2002 (34) 129-135.

[13] Manase, I. Zimbabwean Urban Grooves and their Subversive performance practices. Social Dynamics, 2009:35 (1) 56-67.
[14] Chari, T. Continuity and Change, Impact of Global popula culture on urban grooves music in Zimbabwe. Music Research in Afria, 2009:6 (2) 170-191.

[15] Bere, W. Urban Grooves, The Performance of Politics in Zimbabwes Hip hop Music. Doctor of Philosophy desertation, Department of perfomance Studies. New York Univerity, 2008.

[16] Mateveke, P. [Internet] 2013. Urban groove smusic. Retrieved from jhhsonline.org: http://jhhsonline.org/wp-cont ent/uploads/2014/09/Stunning_the_Nation.pdf

[17] Guchu, W. [Internet] 2005. No amount of scorn will stop urban grooves artistes, . Harare: The Herald Newspaper Zimpapers, 2005-06-16, p.11. Retrived from http://allafrica.com/stories/200506160520.html.

[18] Chimhundu, H. (2010). Background to Language as a constitutional Issue in Zimbabwe. Paper presented at a Training Workshop for Constitutional Outreach Teams, January. Harare, 2010 p 11-15.

[19] Berns, R. Child Family, School community, Socialisation and support. 7th Edition. Belmont: Thompson Wadsworth, 2007.

[20] Manwa, L., \& Ndamba, G. The language of Dress among the Subcultural Group of the Dzimbabwe People in Masvingo, Zimbabwe. Emerging Trends in Educational Research and Policy Studies, 2011: 436-442.

[21] Meekers, D. The noble custom of Roora. The marriage practices of the Shona of Zimbabwe. Ethnology, 1993 (32) $35-54$.

[22] Bere-Chikara, F. Cattle, The life blood of the Sona Society. THE shona customs. Gweru: Gweru Press, 1970.

[23] May, J. Zimbabwean Women in Colonial Custom Law. Gweru: Longman, 1983.

[24] Goody, J. Bride Wealth and Dowry in Africa and Eurasia. Bride Wealth and Dowry. Cambridge Papers in Social Anthropology, 1973 (7) 1-58.

[25] Zimuto, J., \& Chikodza, E. A consumer evaluation of modenity on women dressing. Arts, Science and Commerce., E-ISSN 2229-4686, ISSN 2231-4172, 2013.

[26] Daily News Zimbabwe. [Internet] 2016, January 22). Ban Miniskirts in Schools. Retrieved April 12, 2016, from dailynews.co.zw:https://www.dailynews.co.zw/articles/2016 /01/22/ban-miniskirts-in-schools

[27] McLareen, R. Case Study, Teaching Dance in Zimbabwe, The CHIPAWO experience. Harare: UNESCO, 2001.

[28] The Herald. [internet] 2016, April 04). Traditional dances under threat. Retrieved April 26, 2016, from herald.co.zw: Traditional dances under threathttp://www.herald.co.zw/trad itional-dances-under-threat/

[29] Nehanda Radio. [Internet] 2015, September 27). Mutukudzi Endorses Zim Dancehall. Retrieved April 10, 2016, from nehandaradio.com:

http://nehandaradio.com/2015/09/27/mtukudzi-endorses-zim -dancehall/

[30] De Mello, J., \& Zilberman, E. (2008). Does crime affects economic decisions? An Empirical investigation of savings in high crime environment. be J Econ Poli 8:1-35.

[31] Van Dijck J. Mafia Markets,Assessing organised crime and 
its impact upon societies. Trends in Organised Crime, 2007:10 (3) 39-56.

[32] Katanha, J. Coast Nite: Genesis of a Dream . Nairobi: Signal Press Print, 2010.
[33] Robert, N. (1969). Social Change and History: Aspects of the Western Theory of Development. . New York: Oxford University Press. 